\title{
George Duke, Robert P. George (red.), The Cambridge Companion to Natural Law Jurisprudence, Cambridge University Press, Cambridge 2017, ss. 458
}

Kiedy kilka lat temu Oxford University Press zdecydowało się na wydanie prac zebranych Johna Finnisa (2011), autor postanowił poszczególne tomy uzupełnić o dotychczas niepublikowane fragmenty czy uwagi. Nie był to jednak koniec zainteresowania brytyjskich wydawnictw współczesnymi problemami teorii prawa naturalnego, gdyż niedługo później ukazała się także książka poświęcona twórczości samego Finnisa, pod redakcją Johna Keowna i Roberta P. George’a, w której australijski prawnik poświęcił dużo uwagi swoim polemistom, odpowiadając na niemal wszystkie pojawiające się w tekstach zamieszczonych w tej książce zarzuty (Finnis, 2013, s. 459 i n.). Mnogość - podobnie jak ich różnorodność - zebranych w obydwu tych wydawnictwach artykułów jest wielka, jednak w obu przypadkach zdaje się wysuwać na pierwszy plan pytanie o naturę prawa. Istnieją szkoły czy autorzy, w przypadku których taka perspektywa jest oczywista, ale jeśli bliżej przyjrzeć się twórczości samego Finnisa i jego kolegów z kręgu nowej teorii prawa naturalnego, nie jest to już tak oczywiste. W pracach autorów tradycyjnie zaliczanych do nowej teorii prawa naturalnego da się wyróżnić dwa płynące równolegle strumienie refleksji. Pierwszy dotyczy kwestii tradycyjnie zaliczanych do zagadnień z zakresu teorii czy filozofii prawa, takich jak: pojęcie prawa, relacje prawa i innych systemów normatywnych, ewentualna walidacja prawa itd. (Finnis, 1983, 2001; George, 1995). Z drugiej jednak strony można wskazać, że równie ważne, a w ostatnich latach może nawet ważniejsze są publikacje odnoszące się do zagadnień daleko bardziej praktycznych, mnożonych przez rozwój cywiliza-

1 Agata Czarnecka, Katedra Teorii Prawa i Państwa, Wydział Prawa i Administracji, Uniwersytet Mikołaja Kopernika w Toruniu, Polska, agatato@umk.pl. 
cyjny, jak kwestie aborcji czy związków homoseksualnych (Girgis, 2012; George 2013). Wypada zresztą wspomnieć, że w przypadku przywołanych autorów uwagę zwraca ich wyjątkowa aktywność w sferze publicznej, wynikająca z przekonania o tym, że rola prawa nie sprowadza się jedynie do liberalnego nocnego stróża, ale jest nią również wychowywanie i dbanie nie tylko o materialne, ale też duchowe aspekty życia obywateli, czemu towarzyszy przekonanie o ważnej funkcji samych prawników, których obowiązkiem jest wskazywanie społeczeństwu słusznych sposobów rozwiązywania coraz to nowych dylematów moralnych, a co za tym idzie, także prawnych (George, 1995). Recenzowana tu książka wydaje się pod wieloma względami niezwykła i odbiegająca od kierunku, w jakim wydawało się zmierzać dotychczasowe zainteresowanie przynajmniej jednego z jej współautorów - Roberta P. George’a. Być może jest tak z powodu mnogości autorów, których teksty zebrane zostały w recenzowanym tomie, w wyniku czego - do czego wrócę za chwilę - niekoniecznie ilustruje on przekrój współczesnej myśli prawnonaturalnej.

Seria „Cambridge Companions” ukazuje się od 1986 r. i obejmuje aktualnie ponad sześćset książek. W zamyśle wszystkie one mają być autorskimi przewodnikami omawiającymi z jednej strony pewne zagadnienia problemowe, z drugiej określone idee czy twórczość znaczących postaci historycznych zajmujących się różnymi dziedzinami nauki czy sztuki. Zamysłem całej serii jest przedstawienie zarówno osobom zajmującym się nauką, jak i laikom rzetelnych podręczników-przewodników po wybranych kwestiach. Oczywiście można dyskutować, czy cel ten udało się osiągnąć w przypadku recenzowanego tomu. Debatować przede wszystkim można nad tym, czy w ogóle możliwe jest pogodzenie wymagań, które w przypadku wielu autorów same w sobie stoją w sprzeczności - by książka była jednocześnie zgodna z autorskim zamysłem i zrozumiała dla czytelników o różnym poziomie kompetencji. W przypadku recenzowanego tomu powiedzieć można, że jego eklektyczny treściowo charakter przekłada się również na jedynie częściowe spełnienie tego oczekiwania. Anglosaska, a zwłaszcza amerykańska filozofia prawa czy polityki, zna całe mnóstwo pozycji pisanych językiem zrozumiałym dla osób niezajmujących się zawodowo dyscyplinami, których te pozycje dotyczą. Każdy, kto czytał choćby niektóre książki np. Ronalda Dworkina, Michaela Sandela, czy samego Roberta P. George, doskonale zdaje sobie sprawę z tego, że są one napisane w sposób jasny i przystępny. Nierzadko, szczególnie wśród czytelników przyzwyczajonych do ciężkiej, kontynentalnej, głównie niemieckiej nauki budzi to pewne zdumienie. Jednak recenzowana książka nie jest napisana przystępnym językiem, którego można by od niej oczekiwać. Nie czyta się jej lekko i potoczyście i nie jest ona lekturą, której każdy fragment nadaje się do poduszki. Przynajmniej część jej rozdziałów napisana jest w sposób hermetyczny i raczej mało zrozumiały dla 
osób niezaznajomionych wcześniej z tematem. W żadnym sensie nie odbiera to jej to atrakcyjności dla prawników, wydaje się jednak, że rozdziały napisane przez przywołanego Johna Finnisa czy Roberta Alexego mogą być atrakcyjne w dużej mierze niemal wyłącznie dla osób zainteresowanych teorią czy filozofią prawa. Jednak i tu trzeba przyznać uczciwie, że całość twórczości tych właśnie autorów podziela tę samą - w odczuciu piszącej te słowa - bolączkę, dla innych stanowiącą zapewne jej walor.

Recenzowana książka zgodnie z tytułem ma być więc autorskim przewodnikiem po jurysprudencji prawa naturalnego. Przegląd dotychczasowych wydawnictw z serii pokazuje, że jest to jeden z niewielu tego typu przewodników po zagadnieniach związanych z prawem. Jego redakcję powierzono młodemu badaczowi z uniwersytetu Deakin - George’owi Duke’owi oraz Robertowi P. George’owi znanemu amerykańskiemu prawnikowi, pracującemu na co dzień na Uniwersytecie w Princeton. Robert P. George zaliczany jest do grona autorów z kręgu wspomnianej powyżej nowej teorii prawa naturalnego i wśród autorów tomu znaleźć można kilku jego kolegów; obok Johna Finnisa jest tam także Gerard V. Bradley - redaktor naczelny „The American Journal of Jurisprudence” z uniwersytetu Notre Dame czy Christopher Tollefsen z uniwersytetu Południowej Karoliny. Jednak dobór autorów jest zdecydowanie szerszy i obejmuje także brytyjskich prawników, jak Nigel Simmonds czy Veronica Rodriguez-Bianco, badaczy, którzy zajmują się głównie koncepcjami prawa naturalnego - Marka C. Murphy’ego, czy też autorów z kręgu zdecydowanie szerszej, niepozytywistycznej filozofii prawa - Roberta Alexy’ego. Obecność tego ostatniego jest zresztą szczególnie ciekawa, choćby z tego powodu, że relacje między anglosaską a kontynentalną filozofią prawa wydają się często niedostatecznie bliskie (Alexy, 2013; Finnis, 2014).

Recenzowany tom otwiera wprowadzenie dwóch redaktorów, niezwykle interesujące z punktu widzenia kwestii, na które wskazałam powyżej. Jest oczywistością, że spór wokół pozytywizmu prawniczego nie jest jedynie sporem dotyczącym tezy o rozdziale prawa i moralności. Tym bardziej, jeśli zważyć na zdecydowanie dłuższą historię doktryn prawa naturalnego niż tylko tę, gdy ich głównym przedmiotem zainteresowania były właśnie rozważania dotyczące tezy o rozdziale. Ciężko myśl prawnonaturalną sprowadzić do refleksji na temat związków pomiędzy prawem pozytywnym a innymi porządkami normatywnymi. A jednak to właśnie kwestia obowiązywania prawa niesprawiedliwego i sama teza o rozdziale stały się punktem wyjścia dla redaktorów recenzowanego tomu. Co więcej, mimo tej właśnie bardzo długiej historii jurysprudencji naturalnoprawnej, już zdanie otwierające książkę sytuuje tę jurysprudencję naprzeciw nurtu pozytywistycznego i podejmuje kwestię, która, zdaniem autorów, zaciemnia obraz teorii prawa naturalnego, i sa- 
mego pozytywizmu prawniczego (Duke, 2017, s. 1). Niewiele dalej John Finnis w swoim rozdziale pisze zresztą na ten temat z ironią, wskazując, iż wydawać by się mogło, że aż do czasu pojawienia się pozytywizmu prawniczego cała filozofia prawa bujała w chmurach i była zajęta jedynie moralizowaniem (Finnis, 2011, s. 7). Należy to, jak sądzę, traktować jako pewien rodzaj deklaracji redaktorów, mogący wskazywać na to, na jakie kwestie zostanie w książce położony akcent, a jakie zejdą na dalszy plan. Postawić można wobec tego pytanie - jak na kilkuset stronach pomieścić wielość tradycji, zagadnień i autorów, którzy przez wieki wpisywali się w nurt prawa naturalnego? Wedle jakiego klucza taki przewodnik miałby zostać zbudowany? Pójście tropami historycznymi byłoby niezwykle trudne ze względu zarówno na bogactwo myślicieli wpisywanych w ten nurt, jak i poruszanych przez nich zagadnień, a im bliżej czasów współczesnych, tym byłoby to trudniejsze - czasem bowiem ciężko jest jasno wskazać dystynkcję między doktrynami prawa naturalnego a innymi niepozytywistycznymi nurtami filozofii prawa. Oczywiście możliwa byłaby również droga problemowa i dobór tekstów w taki sposób, by podejmowały one najważniejsze zagadnienia czy problemy, wokół których koncentrowała się ta doktryna. Tylko co czyniłoby dane zagadnienie najważniejszym? Kryterium użyteczności czy aktualności? To oczywiście jedynie wierzchołek góry problemów, mnożących się, gdy stanąć przed próbą napisania syntetycznej książki o prawie naturalnym. Redaktorzy recenzowanego tomu przed tym wyzwaniem stanęli i wybrali rozwiązanie, którego zamysłem wydaje się być jakiś rodzaj kompromisu, z przewagą jednak problemowego doboru poruszanych zagadnień.

Książka podzielona jest na trzy, poprzedzone wstępem, części: „Podstawy”, „Rozumność praktyczna, normatywność i etyka”, „Prawo”. Dobór tekstów wskazuje na to, że autorom dano dużą swobodę w omówieniu zagadnień, co budzi bardzo ambiwalentne wrażenie. $\mathrm{Z}$ jednej strony, dostajemy twórcze i autorskie opracowania problemów, napisane przez autorów, którzy świetnie znają się na poruszanych zagadnieniach (vide Robert Alexy czy Mark C. Murphy), co bez wątpienia stanowi o dużej atrakcyjności recenzowanego dzieła. Z drugiej jednak, książka momentami sprawia trochę wrażenie tomu pokonferencyjnego, do którego autorzy nadesłali teksty na tematy, które oni sami uznają za najbardziej interesujące. To z kolei nasuwa pytanie o to, czy faktycznie jest to najlepszy sposób zbudowania czegoś, co miało być przewodnikiem po najważniejszych, zdaniem redaktorów, zagadnieniach związanych z prawnonaturalną jurysprudencją. Wydaje się bowiem, że zdecydowanie lepszym sposobem zredagowania takiej książki-podręcznika byłoby zakreślenie pól problemowych, a nie zwrócenie się do cenionych przez siebie specjalistów i danie im wolnej ręki. Nie można oczywiście wykluczyć, 
że tak właśnie w przypadku recenzowanego tomu było, jednak - znając historię i aktualne problemy poruszane przez autorów przypisywanych do szkół prawa naturalnego - ciężko takie domniemanie zaakceptować. Po prawdzie zresztą, o ile trudno wymagać systematyczności w przypadku drugiej i trzeciej części książki, gdyż zagadnienia, objęte zakresem tytułowych pojęć są niezwykle szerokie, o tyle część dotycząca podstaw prawa naturalnego jest zbudowana w mocno dyskusyjny sposób, ze względu na próbę pożenienia ze sobą tekstów problemowych z zagadnieniami historycznymi.

Część pierwszą książki otwiera tekst Johna Finnisa na temat św. Tomasza, gdzie autor dość przewrotnie - w kontekście afiliacji samego Finnisa - określa teorię średniowiecznego filozofa jako nową klasyczną teorię prawa naturalnego (Duke, 2017, s. 17). I o ile można by oczekiwać od pierwszej części książki pewnego tła historycznego, o tyle skupia się ona nie tylko na historycznych, ale też na metafizycznych podstawach teorii prawa naturalnego, nie pozostając jednak w oderwaniu od tego, jak można współcześnie skorzystać z prawnonaturalnej spuścizny pierwszych autorów. Znamienne, że w części tej znajduje się także tekst Jonathana Crowe’a „Metaphysical Foundations of Natural Law Theories”, który odnosi się - nieco wbrew tytułowi - nie do teorii prawa naturalnego w ogóle, ale w dużej mierze do samej nowej teorii prawa naturalnego i który równie dobrze mógłby otwierać ostatni fragment recenzowanej książki, gdyż podejmuje kwestie prawnonaturalnej wizji etyki i prawa, co zawsze nieuchronnie zmierza do pytania o naturę samego prawa.

Wśród mnogości poglądów na prawo i jego rolę w koordynowaniu życia wspólnoty można oczywiście - o czym była mowa powyżej - przyjąć stanowisko radykalne, stanowiące, że nie istnieje żaden konieczny związek między nim a innymi porządkami normatywnymi, ale można również postrzegać prawo jako instrument powołany do wyższych celów niż np. sciąganie podatków czy nakładanie mandatów za przekroczenie prędkości. Jeśli by uznać, że rolą filozofii prawa jest również swoista rola drogowskazu, mającego wskazywać słuszne rozwiązania zarówno prawodawcy, jak i kształtować w obywatelach takie postawy, by oczekiwali od prawodawcy rozwiązań określonego rodzaju (a sądzę, że aktywność części autorów tomu w ostatnich latach, w tym też jednego z jego redaktorów, miała niemal wyłącznie taki charakter), to uwagę zwraca fakt, że recenzowana książka jedynie w bardzo ograniczonym zakresie odnosi się do kwestii etycznych. Środkowa część tomu wydaje się więc najbardziej niejednorodna. Z jednej strony znaleźć w niej można rozdział Christophera Tollefsena, mający traktować o dobrach podstawowych i rozumności praktycznej, w istocie jednak stanowiący rekonstrukcję pozycji teoretycznej samej nowej teorii prawa naturalnego, który - tu 
znowu zwraca uwagę pewna niekonsekwencja redakcji - z powodzeniem mógłby znaleźć się we wcześniejszej części książki, dotyczącej podstaw prawa naturalnego. Autor prezentuje zarys koncepcji, podkreślając, że jest ona nową teorią klasyczną i stanowi jedynie pewną rewitalizację teorii, która znana jest przecież od wieków. Pozostaje oczywiście pytanie o to, na ile jest to nadużycie, gdyż trudno faktycznie mówić o jakiejś jednej doktrynie prawa naturalnego kontynuowanej przez wieki. Ostatecznie nowa teoria prawa naturalnego jest próbą uaktualnienia i przystosowania do wyzwań współczesności teorii św. Tomasza i nie jest to zresztą opinia podzielana powszechnie i bezdyskusyjna. W wersji znanej z polskiego przekładu opus magnum Johna Finnisa, a więc „Prawa naturalnego i uprawnień naturalnych” ma ona być też teorią pozbawioną wątków metafizycznych czy religijnych, czyli uzasadnioną argumentami racjonalnymi. Zrekonstruowana przez Tollefsena koncepcja dóbr podstawowych i rozumności praktycznej pomija właściwie jakąkolwiek krytykę skierowaną przeciwko autorom z kręgu nowej teorii, poza małym ukłonem w stronę zarzutów, jakie Russel Hittinger czy Mark C. Murphy postawili szkole, i to tylko w zakresie dotyczącym braku hierarchii dóbr podstawowych i ich wzajemnej niesprowadzalności do siebie. Co zresztą niezwykle interesujące, że o ile Murphy znalazł się w gronie zaproszonych autorów, o tyle dla Russela Hittingera, który nowej teorii prawa naturalnego poświęcił całą książkę (1989) próżno szukać wśród twórców zgromadzonych w recenzowanym tomie.

Można zaryzykować tezę, że dla wielu prawników teorie prawa naturalnego mają znaczenie jedynie jako opozycja wobec prawniczego pozytywizmu. W dużym uproszczeniu dzielą oni przekonanie, że jest to taka teoria, która uznaje, że źródłem prawa jest coś więcej niż tylko prawo stanowione. W skrajnej wersji teoria taka miałaby być zbędna z powodu jej nieużyteczności w roli argumentu w postępowaniu sądowym. To oczywiście banalizacja i pozbawienie takich przekonań jakichkolwiek niuansów. Jednak pozostaje faktem, że teorie prawnonaturalne, choć przeżywają swój renesans, nie wiodą prymu we współczesnej filozofii prawa, a co za tym idzie - wielu czytelnikom pozostają znane jedynie z nazwy. Tymczasem właśnie refleksja tego typu szkół dotycząca prawa jest niezwykle różnorodna i niepozbawiona sporów, a teorie te mają wiele do zaoferowania samemu prawu. Przykładem może być ta przedstawiona przez Marka Greenberga w rozdziale „The Moral Impact Theory, the Dependence View and Natural Law”, gdzie autor stara się wpisać teorię moralnego oddziaływania do grupy poglądów, które nazywa zależnymi. Co ciekawe, jest ona różna zarówno od klasycznych teorii prawa naturalnego, ale też od innych poglądów niepozytywistycznych, mimo że pozostaje poszukiwaniem odpowiedzi o naturę prawa i o to, jakie właściwie są jego podstawy, co tak naprawdę kryje się za faktami prawnymi, czym są tzw. fakty podstawowe, 
które sprawiają że prawo nabiera mocy obowiązującej? Zwraca zatem uwagę fakt, że w części poświęconej samemu prawu następuje daleko większe zróżnicowanie teoretyczne niż w przypadku dwóch poprzednich części recenzowanej pracy. Jednak i ono budzi pewną wątpliwość, gdyż - jak widać z tego lakonicznego opisu teorii Greenberga i co dość powszechnie wiadomo o twórczości choćby Roberta Alexy’ego - postawić można pytanie, czy mamy wciąż do czynienia z teoriami prawa naturalnego, czy też po prostu z pewnym przeglądem teorii niepozytywistycznych, które niekoniecznie da się do teorii prawnonaturalnych zaliczyć. Kiedy Robert Alexy podejmuje temat prawa i zastanawia się nad jego wymiarem realnym i idealnym, to nie przedstawia jurysprudencji prawa naturalnego, a jedynie taką, którą nazywamy niepozytywistyczną. Jego wspomniana powyżej polemika z Johnem Finnisem również zresztą nie odbywała się z tych samych, ale raczej dość krytycznych względem siebie pozycji. Nie umniejsza to w żadnym sensie przywołanym teoriom, jednak w pewnym sensie zakłamuje samą ideę tomu, który miast być przeglądem koncepcji prawa naturalnego, stał się przeglądem koncepcji niepozytywistycznych.

Należy podkreślić, że bez względu na podniesione powyżej uwagi krytyczne, które - zdaniem piszącej te słowa - są zazwyczaj wynikiem zainteresowania czytelnika dziełem i wnikliwej lektury, „The Cambridge Companion to Natural Law Jurisprudence” pozostaje książką bardzo ciekawą, pokazującą, że teorie prawa naturalnego są ciągle żywe i nie pozostają głuche na problemy trapiące współczesny świat. Co więcej, mimo upływu wieków wciąż mają wiele do zaoferowania w zakresie rozwiązywania problemów etycznych i prawnych, a ponieważ jest ich tylko coraz więcej, recenzowana książka pozostaje lekturą godną polecenia.

\section{Bibliografia}

Alexy, R. (2013). Some Reflection on the Ideal Dimension of Law and on the Legal Philosophy of John Finnis. The American Journal of Jurisprudence, 58(2), s. 97-110.

Duke, G, George R.P. (2017). Introduction. W: G. Duke. R.P. George (red.), The Cambridge Companion to Natural Law Jurisprudence. Cambridge: Cambridge University Press.

Finnis, J. (2011). Collected Essays. Oxford: Oxford University Press.

Finnis, J. (1983). Fundamentals of Ethics. Georgetown: Georgetown University Press.

Finnis, J. (2011), Introduction. W: J. Finnis. Philosophy of Law. Oxford: Oxford University Press 2011.

Finnis, J. (2001). Prawo naturalne i uprawnienia naturalne. Warszawa: Dom Wydawniczy ABC.

Finnis, J. (2013). Reflection and Responses. W: J. Keown, R.P. George (red.), Reason, Morality, and Law. The Philosophy of John Finnis. Oxford: Oxford University Press. 
Finnis, J. (2014). Law as Fact and as Reason for Action: A Response to Robert Alexy on Law's Ideal Dimension. The American Journal of Jurisprudence, 59(1), s. 85-109. Girgis, S, George R.P., Anderson R.T. (2012). What is Marriage? Man and Woman: A Defense. Encounter Books.

George, R.P. (2013). Conscience and Its Enemies: Confronting the Dogmas of Liberal Secularism. ISI Books.

George, R.P. (1995). Making Men Moral. Civil Liberties and Public Morality. Clarendon Press.

Hittinger, R. (1989), A Critique of the New Natural Law Theory. Notre Dame: University of Notre Dame Press. 